151

Received: June 28, 2012

Accepted: December 6, 2012
Macedonian Journal of Animal Science, Vol. 3, No. 1, pp. 69-73 (2013)

In print ISSN $1857-6907$

On line ISSN 1857 - 7709

UDC: $636.4 / .5 .086$

Original scientific paper

\title{
RAPESEED MEAL IN NON-RUMINANT NUTRITION
}

\author{
Vladislav Stanaćev ${ }^{1}$, Dragan Milić ${ }^{1}$ Ana Marjanović Jeromela ${ }^{2}$, Vidica Stanaćev ${ }^{3}$, \\ Niko Milošević ${ }^{3}$, Nikola Puvača ${ }^{3}$ \\ ${ }^{1}$ Perutnina Ptuj, Topiko doo, Petefi Brigade 2, 23400 Bačka Topola, Serbia \\ ${ }^{2}$ University of Novi Sad, Institute for Field and Vegetable Crops, \\ Maksima Gorkog 30, 21000 Novi Sad, Serbia \\ ${ }^{3}$ University of Novi Sad, Faculty of Agriculture, Department of Animal Science, \\ Trg Dositeja Obradovića 8, 21000 Novi Sad, Serbia \\ vidica.stanacev@stocarstvo.edu.rs
}

\begin{abstract}
Nutritive value of rapeseed meal and possibility of replacment of soybean meal by rape meal in the nutrition of pigs and poultry use are given in this paper. Rapeseed meal low in antinutritional factors is possible to be applied up to $5 \%$ in nutrition of piglets and $10 \%$ in nutrition of sows and fattening pigs. There is also the possibility that the rapeseed meal replaces totally soybean meal in the nutrition of sows and pigs in the second phase of fattening without any negative effects to animals. The limited level of rapeseed meal in the nutrition of young categories of pigs is caused by their higher needs of energy and aminoacids. In broilers nutrition usage of rapeseed meal of different cultivars in amount of $5 \%$ did not significantly effect the body weight in the first period of fattening. Effect of cultivar was very significant. The best results were obtained with the cultivar Slavica, then NS-07 and Banaćanka, respectively on the performances of the chickens in all the groups in comparison with the control group. Feed conversion ratio was increased in both periods of fattening as well as in the entire experiment.
\end{abstract}

Key words: Rapessed meal; pigs; glucosinolates; rapeseed cultivars; chickens

\section{К'УСПЕ ОД МАСЛОДАЈНА РЕПКА ВО ИСХРАНАТА НА НЕПРЕЖИВНИТЕ ЖИВОТНИ}

Во трудот се претставени нутритивната вредност на ќуспето од маслодајната репка и можноста за замена на соиното ќуспе со репкино ќуспе во исхраната на свињите и живината. Ќуспето од маслодајната репка содржи ниско ниво на антинутритивни фактори и може да биде воведено до $5 \%$ во исхраната на прасињата и до $10 \%$ во исхраната на маториците и свињите за гоење. Во втората фаза на гоење на маториците и свињите постои можност за целосна замена на соиното ќуспе со ќуспето од маслодајната репка, без при тоа да постојат какви било негативни ефекти врз животните. Употребата на ќспето од маслената репка во исхраната на младите категории свињи е ограничена поради нивната голема потреба од храна богата со енергија и аминокиселини. Куспето од маслодајната репка добиено од различни сорти репка, во количина од 5\% во исхраната на бројлери не влијае сигнификантно врз живата маса на бројлерите во првиот период од гоењето. Влијанието на сортите маслодајна репка беше сигнификантно во однос на перформансите на кокошките. Најдобри резултати беа добиени со сортата славица, потоа со сортата NS-07 и баначанка во однос на перформансите на пилињата од сите групи во споредба со контролната група. Степенот на конверзија на храната беше зголемен во текот на целиот експеримент во двата периода на гоење.

Клучни зборови: ќуспе од маслодајна репка; свињи; глукосинолати; сорти маслодајна репка; пилиња

\section{INTRODUCTION}

Production of protein feed in Serbia does not meet the needs of livestock production, so the import mainly provides protein feedstuffs such as soybean meal and fish meal in large amount, and then the other protein sources in much smaller quantities. In such conditions, sufficient amounts of raw materials are not provided for full capacity utilization of plant oils. In order to solve this problem in the past attention has been devoted to the improvement and expansion of soybean and sun- 
flower oils as raw material for production of oil for human consumption and protein feed for animals, while the production of rapeseed was neglected and almost abandoned.

The need for biodiesel production as well as progress in the selection of oilseed rape, made to this feed becomes interesting for our production. In addition to the aforementioned canola is a crop that requires minimal processing, and its cultivation helps prevention of further spread of weeds. For these reasons, rapeseed meal reappeared as a protein feed that will reduce the deficit in protein, but only if it is rationally used in the diet.

Rapeseed is the oldest European oilseed, dating from the early XIII century and is the world widespread plant. Different varieties are sown and when it is taken into account the percentage of erucic acid should not exceed $2 \%$ and to be with as few or no glucosinolates. The seed of modern varieties contain 38 to $48 \%$ oil and 18 to $28 \%$ protein. The content of erucic acid is below $0.1 \%$, and the content of glucosinolates is no higher than 10 $\mu \mathrm{mol} / \mathrm{g}$.

The nutritive value of feedstuffs was for a long time limited by the presence of antinutritional factors - glucosinolates and erucic acid, which gave rise to serious disturbances in animals and restricted its use, besides amino acid composition of high-quality (Segedlija, 1980). High levels of glucosinolates was causing disturbances in the metabolism of iodine and thyroid function, and the content of unsaturated long-chain erucic acid led to damage the heart muscle and grease. In the literature for a long time data appeared on the selec- tion of new varieties of rapeseed called canola, which do not contain erucic acid and glucosinolates, or the content of these compounds is reduced several times, so-called " 00 " variety whose processing is gained meal or cake with high nutritional value.

\section{NUTRITIVE VALUE OF GRAIN, RAPESEED MEAL AND RAPESEED CAKE}

Rapeseed meal is feed that contains plenty of protein, good amino acid composition but with low and variable amount of energy, because of its high cellulose content and low digestibility of nutrients (Tables 1 and 2). Compared with other feed protein, rapeseed meal has a good amino acid composition, high content of micro and macro elements, especially phosphorus, whose efficiency is better despite the presence of phytic acid but has a lower energy value (Nwokolo and Bragg, 1977, Keith and Bell, 1987; Stanaćev et al., 2002; Stanaćev et al., 2003; Stanaćev and Kovčin, 2004; Stanaćev et al., 2011). Rapeseed has a higher energy value than soybean and sunflower oil and animal fats if it comes from newer varieties with low erucic acid. In the diet it can also be used as a grain and seed in a mixture of proteins and enters the next higher energy (Clandinin et al., 1981; Saben et al., 1981, Kennelly et al., 1978, Sauer et al., 1982). It should be noted that canola meal has poor taste and should be gradually introduced to the diets in order not to reduce feed consumption (Živković, 1978).

Table 1

Chemical composition and nutritive value of grain and rapeseed meal

\begin{tabular}{|c|c|c|c|c|c|}
\hline \multirow{2}{*}{ Nutrients } & \multirow{2}{*}{ Rape seed } & \multicolumn{4}{|c|}{ Rapeseed meal } \\
\hline & & NRC 1984 & Esminger et al., 1990 & Leeson and Summers, 1997 & Stanaćev et al., 2002 \\
\hline Crude protein, $\%$ & 22.00 & 38.00 & 35.60 & 37.50 & 32.37 \\
\hline Crude fat, $\%$ & 40.00 & 3.80 & 7.30 & 1.80 & 4.18 \\
\hline Crude fibers, $\%$ & 6.00 & 11.10 & $12: 00$ & 11.90 & 13.70 \\
\hline $\mathrm{Ca}, \%$ & $0: 38$ & 0.68 & 0.66 & 0.66 & 0.58 \\
\hline $\mathrm{P}$ total, $\%$ & - & 1.17 & 1.04 & - & 0.98 \\
\hline $\mathrm{P}$ available, $\%$ & 0.27 & 0.30 & - & 0.47 & - \\
\hline $\mathrm{SE} \mathrm{MJ} \mathrm{/} \mathrm{kg}$ & - & - & 12.60 & - & 11.37 \\
\hline
\end{tabular}


Table 2 .

The protein content and amino acids in soybean, sunflower and rapeseed meal

\begin{tabular}{lcccccc}
\hline \multirow{2}{*}{ Nutrients } & \multicolumn{2}{c}{ Soybean meal } & \multicolumn{2}{c}{ Sunflower meal } & \multicolumn{2}{c}{ Rapeseed meal } \\
\cline { 2 - 7 } & Content & Digestibility & Content & Digestibility & Content & Digestibility \\
\hline Protein, \% & 44.00 & 80.00 & 35.29 & 75.00 & 37.28 & 69.00 \\
Lysine, \% & 2.81 & 86.00 & $1: 30$ & 74.00 & 2.19 & 73.00 \\
Methionine, \% & 0.67 & 85.00 & 0.78 & 87.00 & 0.98 & 82.00 \\
Threonine, \% & 1.74 & 76.00 & 1.26 & 71.00 & 1.78 & 68.00 \\
Tryptophan, \% & 0.53 & 80.00 & 0.42 & 76.00 & 0.43 & 71.00 \\
\hline \hline
\end{tabular}

\section{POSSIBILITY AND EFFECTS OF USAGE RAPESEED MEAL IN PIG NUTRITION}

Rapeseed meal is similar to sunflower meal by its nutritive value protein and mineral content. In the diet of pigs it can be used as a source of protein, but hardly can be the only source and to replace soybean meal completely. In finding the optimal level of canola meal in the diet of pigs numerous researchers are involved and they get conflicting results (McKinnon and Bowland, 1977; Ochteim et al., 1980, McIntosh et al., 1986). McIntosh et al. (1986) compared the quality of the starter mixture in which $0,25,50,75$ and $100 \%$ protein soybean meal was replaced by canola meal and found that the amount of $9 \%$ is maximum that could be included in the pigs diet (Table 3). Higher levels can significantly reduce the performance of piglets due to reduced feed intake, because this is tasteless feed, and pigs are reluctant to consume it (Baidoa et al., 1986). Possibility of pigs to feel the taste of feed and to detect the presence of canola even in small quantities in the diet was proved by Baidoa et al. (1987) and suggested on the basis of the experiments that its participation in the Starter mixture should be limited to $5 \%$ for these reasons.

When it comes to fattening pigs McKinnon and Bowland (1977) studied the effect of replacing 50 and $100 \%$ of soybean meal protein with canola meal in the first phase of the fattening period and found that the total replacement of protein led to a significant reduction in daily gain and efficiency of feed utilization. However, in pigs fed on diets with soybean and canola meal there was a similar gain and efficiency of feed utilization as the sole dietary soybean meal. According to these authors the maximum amount of canola meal in grower diets can be $9 \%$ (Table 4).

Table 3

Effect of canola meal

on the production of weaned pigs from 7 to $15 \mathrm{~kg}$

\begin{tabular}{lrrrrr}
\hline \hline $\begin{array}{l}\text { Participation of } \\
\text { canola meal, \% }\end{array}$ & 0.00 & 9.00 & 18.00 & 27.00 & 36.00 \\
$\begin{array}{l}\text { Soy protein replaced } \\
\text { with canola, \% }\end{array}$ & 0.00 & 25.00 & 50.00 & 75.00 & 100.00 \\
$\begin{array}{l}\text { Daily gain, g } \\
\begin{array}{l}\text { Feed consumption, } \\
\text { g/day }\end{array}\end{array}$ & 295.00 & 301.00 & 269.00 & 238.00 & 223.00 \\
$\begin{array}{l}\text { Feed conversion, } \\
\text { kg/kg }\end{array}$ & 570.00 & 537.00 & 492.00 & 447.00 & 433.00 \\
\hline \hline & 1.94 & 1.79 & 1.85 & 1.89 & 1.98 \\
\hline Mcintosh et al. (1986) & & & & & \\
\end{tabular}

Table 4

$$
\begin{gathered}
\text { Effect of canola meal } \\
\text { in pig production from } 20 \text { to } 40 \mathrm{~kg}
\end{gathered}
$$

\begin{tabular}{|c|c|c|c|}
\hline Participation of canola meal, $\%$ & 0.00 & 9.30 & 19.80 \\
\hline $\begin{array}{l}\text { Soy protein replaced with } \\
\text { canola, } \%\end{array}$ & 0.00 & 50.00 & 100.00 \\
\hline Daily gain, $g$ & 640.00 & 630.00 & 550.00 \\
\hline Feed consumption, $\mathrm{kg}$ /day & 1.67 & 1.68 & 1.63 \\
\hline Feed conversion, $\mathrm{kg} / \mathrm{kg}$ & 2.63 & 2.67 & 2.96 \\
\hline
\end{tabular}

Mc Kinnon and Bowland (1977)

For pigs in the second stage of fattening numerous literature data indicate that canola meal can completely replace soybean meal protein 
without a negative impact on feed consumption and weight gain, and carcass quality (Bell et al., 1981, Aherne and Lewis, 1978; Narendran et al ., 1981). McKinnon and Bowland (1977) experimentally verifyfied this hypothesis by replacing 50 and $100 \%$ soybean meal with canola meal in the diet of pigs in the second fattening period and found that the total replacement of soybean meal does not affect the performance of pigs and also lowers feeding costs (Table 5).

Table 5

\section{Effect of canola meal on the production of fattening pigs from 40 to $85 \mathrm{~kg}$}

\begin{tabular}{lrrr}
\hline $\begin{array}{l}\text { Participation of canola } \\
\text { meal,\% }\end{array}$ & 0.00 & 6.10 & 12.60 \\
$\begin{array}{l}\text { Soy protein replaced with } \\
\text { canola, \% }\end{array}$ & 0.00 & 50.00 & 100.00 \\
$\begin{array}{l}\text { Daily gain, g } \\
\text { Feed consumption, kg/day }\end{array}$ & 620.00 & 580.00 & 580.00 \\
Feed conversion, kg/kg & 3.80 & 2.25 & 2.24 \\
\hline \hline
\end{tabular}

McKinnon and Bowland (1977)

Canola meal can also replace soybean meal in the diet of sows, and not to lead to decrease of litter size or weight of weaned piglets.

In poultry nutrition, according to the earlier data, when older selection of this crop was used, rapeseed meal had a strong depressing effect on production, and increased thyroid gland. However, the production of cultivars with reduced levels of antinutritional factors has created the possibility of usage of rapeseed meal in quantities up to $5 \%$ in the starter diets and $8 \%$ in the finisher diet in broilers (Leeson and Summers, 1997; Mykytyn, 2003).

Stanaćev Vidica et al. (2006) examined the effect of different meal varieties of rapeseed (Slavica, Banaćanka, NS-07) on the performance of broilers. The use of this meal in the amount of $5 \%$ had no significant effect on the body weight in the first fattening period (Table 6). However, the increased participation of rape in finisher diets to $10 \%$, exhibited a pronounced depressant effect in groups where they used varieties Banaćanka and NS-07. The body weight was decreased by $7.43 \%$ and $5.20 \%$ (Table 7). The reason for this is probably a higher level of glucosinolates and lower energy value when compared to Slavica (Table 6).
However, the effect is enhanced compared to the old variety, in which the weight reduction ranged up to $25 \%$ according to the research done by Clandinin et al. (1981). The effect of the cultivar Slavica is almost identical to the control group, which is consistent with the parameters of its quality.

\section{Table 6}

The composition of rapeseed meal used in broilers nutrition

\begin{tabular}{lccc}
\hline \hline Nutrients & Slavica & Banaćanka & NS-07 \\
\hline Crude protein, \% & 29.16 & 29.11 & 28.61 \\
Crude fat, \% & 20.56 & 19.75 & 20.61 \\
Crude cellulose, \% & 7.20 & 6.96 & 10.48 \\
Ash, \% & 4.72 & 4.69 & 5.39 \\
Ca, \% & 0.37 & 0.39 & 0.49 \\
P, \% & 0.75 & 0.77 & 0.93 \\
Glucosinolates, $\mu \mathrm{mol} / \mathrm{g}$ & 15.05 & 17.95 & 17.06 \\
\hline \hline
\end{tabular}

Stanaćev et al. (2006)

Table 7

Body mass of broilers, $g$

\begin{tabular}{|c|c|c|c|c|}
\hline & \multicolumn{4}{|c|}{ Group and the variety of rapeseed } \\
\hline & Control & Slavica & Banaćanka & NS-07 \\
\hline $\begin{array}{l}\text { The share of rapese- } \\
\text { ed meal from } 0 \text { to } 21 \\
\text { day, } \%\end{array}$ & 0.00 & 5.00 & 5.00 & 5.00 \\
\hline $\begin{array}{l}\text { The average body } \\
\text { weight } 21 \text { days, g }\end{array}$ & 520.50 & 523.00 & 515.70 & 543.00 \\
\hline Index, \% & 100.00 & 100.48 & 99.08 & 104.32 \\
\hline $\begin{array}{l}\text { The share of rapese- } \\
\text { ed meal from } 21-42 \\
\text { day, } \%\end{array}$ & 0.00 & 10.00 & 10.00 & 10.00 \\
\hline $\begin{array}{l}\text { The average body } \\
\text { weight for } 42 \text { days, } g\end{array}$ & 1871.90 & $1863.70^{\mathrm{ns}}$ & $1732.90^{* *}$ & $1774.60^{* *}$ \\
\hline Index, $\%$ & 100.00 & 99.56 & 92.57 & 94.80 \\
\hline
\end{tabular}

Stanaćev et al. (2006); ns - not significant; ** - significantly $(\mathrm{P}<0.01)$

Feed conversion was increased in groups with rapeseed meal in both periods and the entire experiment (Table 8). 
Table 8

\section{Feed conversion, $\mathrm{kg}$}

\begin{tabular}{|c|c|c|c|c|}
\hline & \multicolumn{4}{|c|}{ Group and the variety of rapeseed } \\
\hline & Control & Slavica & Banaćanka & NS-07 \\
\hline $\begin{array}{l}\text { The share of } \\
\text { rapeseed meal from } 0 \\
\text { to } 21 \text { day, } \%\end{array}$ & 0.00 & 5.00 & 5.00 & 5.00 \\
\hline $\begin{array}{l}\text { The average } \\
\text { conversion of } 21 \\
\text { days, } \mathrm{kg}\end{array}$ & 1.68 & 1.94 & 1.86 & 1.82 \\
\hline Index, $\%$ & 100.00 & 115.48 & 110.71 & 108.33 \\
\hline $\begin{array}{l}\text { The share of } \\
\text { rapeseed meal from } \\
21 \text { to } 42 \text { day, } \%\end{array}$ & 0.00 & 10.00 & 10.00 & 10.00 \\
\hline $\begin{array}{l}\text { The average } \\
\text { conversion of } 42 \\
\text { days, } \mathrm{kg}\end{array}$ & 2.02 & 2.08 & 2.32 & 2.13 \\
\hline Index, $\%$ & 100.00 & 102.97 & 114.85 & 105.44 \\
\hline $\begin{array}{l}\text { Average - the entire } \\
\text { experiment, kg }\end{array}$ & 1.85 & 2.01 & 2.09 & 1.98 \\
\hline Index, \% & 100.00 & 108.65 & 112.97 & 107.03 \\
\hline
\end{tabular}

Stanaćev et al. (2006)

Acknowledgements: This work was funded under the project TR-31033, which is funded by the Ministry of Science and Technological Development of Republic of Serbia.

\section{REFERENCES}

[1] Aherene, F. X., Lewis, A. J. (1978): The nutritive value of tower rapeseed meal for swine. Animal. Feed Sci. Technol., 3, 235-242.

[2] Baidoo, S. K., Mcintosh, M. K., Aherne, F. X. (1986): Selection preferences of starter pigs fed canola meal and soybean meal supplemented diets. Can. J. Anim. Sci., 66, 1039-1049.

[3] Baidoo, S. K., Mitaru, B. N., Aherne, F. X., Blir, R. (1987): The nutritive value of canola meal for early weaned pigs. Animal. Feed Sci. Technol., 18, 45-53.

[4] Bell, J. M., Anderson, D. M., Shires, A. (1981): Evaluation of candle rapeseed meal as a protein supplement for swine. Can. J. Anim. Sci., 61, 453-461.

[5] Clandinin, D. R., Robblee, A. R., Singer, S. J., Bell, J. M. (1981): Composition of canola meal. In: D. R. Clandinin Ed. Canola Meal for Livestock and Poultry. Canola Council of Canada, Publ., No. 59, 8-11.

[6] Ensminger, M. E., Oldfield, J. E., Heinemann, W. W. (1990): Feeds and Nutrition Digest. University book.
[7] Keith, M., Bell, J. (1987): Effect of canola meal on tissue trace mineral concentrations in groving pigs. Can. J. Anim. Sci., 67, 133-140.

[8] Kennelly, J. J., Aherne, F. X., Lewis, (1978): The effect of isolation, or varietal differences in high fiber hull fraction of low glucosinolate rapeseed meals on rat or pig performance. Can. J. Anim. Sci., 58, 743-752.

[9] Leeson S., Summers J. D. (1997): Commercial Poultry Nutrition. University books, Guelph, Ontario, Canada.

[10] Mcintosh, M. K., Baidoo, S. K., Aherne, F. X., Bowland, J. P. (1986): Canola meal as a protein supplement for 620 kg pigs. Can. J. Anim. Sci., 66, 1051-1056.

[11] McKinnon, P. J., Bowland, J. P. (1977): Comparison of low glucosinolate - low erucic acid rapeseed meals and soybean meal as a source of protein for starting, growing and finishing pigs and young rats. Can. J. Anim. Sci., 57, 663-678.

[12] Mykytyn, S. M. (2003): Improved rapeseed meal in the nutrition of broiler chikens. Proceedings of the 11th International Rapeseed Congress, Copenhagen, Denmark, 1231-1233.

[13] Narendran, R., Boweman, G. H., Leeson, S., Pfeiffer, W. (1981): Effect of different levels of tower rspeseed mesl in corn-soybean based diets on growing-finishing pig performance. Can. J. Anim. Sci., 61, 213-216.

[14] Nutrient Requirements of Poultry, NRC. (1994): National Academy Press, Washington, D,C.

[15] Nwokolo, E. N., Bragg, D. B. (1977): Influence of fytic acid and crude fiber on the availability of minerals from four protein suplements in growing chicks. Can. J. Anim. Sci., 57, 475-477.

[16] Ochetim, S., Bell, J. M., Doige, C. E., Young C. G. (1980): The feeding value of tower rapeseed meal for early weaned pigs. i. effects of methods of processing and of dietary levels. Can. J. Anim. Sci., 60, 407-421.

[17] Saben H. S., Bowland J. P., Hardin R. T. (1981): Digestible and metabolisable energy values for rapeseed meals feed to growing pigs. Can. J. Anim. Sci., 51, 419425.

[18] Sauer, W. C., Cichon, R., Misir, R. (1982): Aminoacid availability and protein quality of canola rapeseed meal for pigs and rats. Can. J. Anim. Sci., 54, 292-297.

[19] Segedlija, Đ. (1980): Utjecaj hranidbene vrijednosti sačme uljane repice $u$ ishrani svinja u porastu $i$ tovu. Doktorska disertacija, Poljoprivredni fakultet, Novi Sad.

[20] Stanaćev, V., Kovčin, S. (2004): Parametri kvaliteta uljane repice. 45. Savetovanje „Proizvodnja i prerada uljarica", Zbornik radova, 45, 127-132.

[21] Stanaćev, V., Kovčin, S., Furman, T., Nikolić R., Savin, L., Tomić, M. (2002): Hemijski sastav i hranljiva vrednost domaće sačme uljane repice. Traktori $i$ pogonske mašine, 7 (2), 80-83.

[22] Stanaćev, V., Kovčin, S., Marinković, R. (2003): Hemijski sastav sačme i pogače nekih sorata uljane repice. 44. Savetovanje „Proizvodnja i prerada uljarica“, Zbornik radova, 44, 259-263.

[23] Stanaćev, V., Kovčin, S., Stanaćev, V., Pucarević, M., Puvača, N. (2011): Extruded canola seed in improving chicken fattening and fatty acid composition. Kuwait $J$. Sci. Eng., 38 (1A), 71-80.

[24] Živković, S. (1978): Ishrana svinja. Univerzitetski udžbenik. Poljoprivredni fakultet, Novi Sad. 